\title{
B-chromosome selection in Allium schoenoprasum II. Experimental populations
}

\author{
D. S. HOLMES \& S. M. BOUGOURD \\ Department of Biology, University of York, York, Y01 5DD, U.K.
}

\begin{abstract}
Experimental populations were set up in the glasshouse in order to investigate the factors responsible for the increase in B-chromosome frequency between the seed and seedling stages of Allium schoenoprasum at the River Wye, Powys, S. Wales. Both the density of sowing $(100,250,500$ and 1000 seeds per pot) and the availability of moisture (normal, waterlogged and drought) were varied in the experimental system, which involved growing plants in small plastic multipots. Sowing density had no effect on the B-chromosome constitution of survivors, but the effect of moisure on the proportion of B-containing plants amongst the survivors was significant at the 5 per cent level. Moisture also had a significant effect on the proportion of non-standard B-types amongst the survivors. Drought conditions had the most pronounced effects, and the significance of this is discussed in relation to the conditions encountered by A. schoenoprasum at the River Wye.
\end{abstract}

Keywords: Allium schoenoprasum, B-chromosomes, fitness, germination, population cytogenetics, selection.

\section{Introduction}

The role of B-chromosomes has been the subject of considerable discussion and speculation for many years (Darlington, 1956; Jones, 1975; Jones \& Rees, 1982). A widely favoured view is that B-chromosomes have no adaptive role but are maintained in populations as a result of accumulation mechanisms which serve to balance the negative selection that operates against individuals or gametes that carry them (Östergren, 1945; Nur, 1977; Matthews \& Jones, 1983). This view takes little account of cases where B-chromosomes appear to be associated with selectively advantageous effects. We have described recently a situation in Allium schoenoprasum at the River Wye, Powys where $\mathrm{B}$-chromosomes confer a selective advantage to the survival of individuals during the early stages of the life-cycle (Holmes \& Bougourd, 1989). A highly significant increase in the frequency of B-containing individuals was found to occur between the seed and seedling stages; approximately 64 per cent of seedlings collected from the sample area contained B-chromosomes compared with only about 55 per cent of individuals grown up from a seed sample collected from the same area earlier in the season. We proposed that this selective advantage of B-containing individuals during the crucial early stages of the life-cycle may be sufficient to maintain the B-chromosome polymorphism at the River Wye despite the apparently deleterious effects of $\mathrm{Bs}$ on adult plants and the absence of an effective accumulation mechanism (Bougourd \& Parker, 1979a).

It is difficult to define precisely the conditions at the River Wye that are responsible for the differential survival of B-containing individuals. However, it is clear that only a very small proportion of the seeds produced by plants at the River Wye survive as seedlings until the autumn, and one of the most important factors influencing survival appears to be the availability of moisture for early germination and subsequent establishment of the seedlings before the dramatic rise in the river level at the end of the summer (Holmes \& Bougourd, 1989). In the work described here, experimental populations were set up in the glasshouse in which both the density of sowing and the availability of moisture were varied in order to investigate the factor or factors responsible for the increase in B-chromosome frequency between the seed and seedling stages at the River Wye. The experimental system, which involved growing plants in small plastic multipots, was similar to that devised by Rees \& Hutchinson (1973) in their studies of the fitness of individuals with B-chromosomes in Lolium perenne and Secale cereale.

\section{Materials and methods}

\section{Materials}

Fruiting umbels of $A$. schoenoprasum were collected at random from populations at the River Wye that had 
previously been shown to have high B-chromosome frequencies (populations ' $\mathrm{B}$ ' and ' 5 ', Bougourd \& Parker, 1979b). Only apparently viable seeds, chosen on the basis of their firmness, were used in the experiments.

\section{Density experiments}

Seeds were sown in Levington Universal compost in $4 \mathrm{~cm}$ diameter pots at densities of 5, 25, 50, 100, 250, 500,750 and 1000 seeds per pot. There were two replicates of each sowing density (A and $B$ ), each replicate consisting of 10 pots sown at the appropriate density to boost the numbers of seedlings surviving in any one replicate.

\section{Watering regimes}

The density experiments were subjected to each of three watering regimes: normal, waterlogged, and drought.

Normal. Approximately $2 \mathrm{~cm}^{3}$ of water per pot was delivered once a day via an automated mist spray unit.

Waterlogged. Pots were placed in polystyrene containers which were kept filled with fresh water. The container was subdivided from the rim of the pot upwards to prevent seeds floating to neighbouring pots.

Drought. Approximately $2 \mathrm{~cm}^{3}$ of water per pot was delivered twice weekly via a second automated mist spray unit.

The 16 groups of 10 pots (two replicates each of eight sowing densities) in the normal and drought regimes were arranged in trays at random around their respective mist spray units. Each group of 10 pots in the waterlogged regime was placed in a separate polystyrene container, and the 16 containers randomized within the glasshouse.

\section{Germination and survival rates}

The numbers of seeds that had germinated in each pot were recorded at regular intervals, and the numbers of survivors throughout the experiment were scored by counting the sheathing leaf bases visible above the compost. At the end of the experiment, a final count of survivors was made by counting the number of bulbs present in the pot. Very few bulbs had evidence of rhizome remains, so it can be assumed that surviving bulbs represented individual genets.

\section{Chromosome counts}

On the basis of relative survival rates after 38 weeks, it was decided to examine cytologically a random sample of 25 genets from each pot sown with 100, 250, 500 and 1000 seeds from each watering regime. Where there were less than 25 survivors per pot, all the individuals were examined. The plants chosen for analysis were potted up individually in Levington Universal compost. Root tips were pretreated with 0.05 per cent colchicine for $2 \mathrm{~h}$, fixed in $1: 3$ acetic-alcohol and stained by the Feulgen method.

\section{Results}

\section{Survival}

The data for the relative survival of seedlings after 38 weeks under the density and watering regimes chosen for analysis are given in Table 1. The percentage surviving under normal watering conditions, decreased with increasing sowing density, from a maximum of 35 per cent at 100 seeds per pot to about 16 per cent at 1000 seeds per pot. Similarly, in waterlogged conditions, the percentage surviving fell from about 34 per cent at 100 seeds per pot to less than 10 per cent at 1000 seeds per pot. The number of survivors remained more or less constant after the first 2 weeks, which suggests that under these conditions it is germination and early establishment of seedlings that is important in determining the longer-term survival of individuals. In drought conditions, a very limited amount of germination occurred over a longer period of about 8 weeks, and a correspondingly low number of seedlings $(<3$ per cent $)$ were present in the pots at all sowing densities after 38 weeks, with the same trend of lower survival at higher sowing densities.

\section{B-chromosome constitution of survivors}

The percentage of plants containing B-chromosomes amongst the survivors for each density and moisture level is also given in Table 1, together with the distribution of B-chromosome number and the mean number of B-chromosomes per plant. The types of B-chromosomes amongst the survivors are given in Table 2.

The data were analysed using the GLIM Statistical Package (Royal Statistical Society, London, 1989). Logit analysis was used to compare the frequency of B-containing plants amongst the survivors of the various regimes (Table 3 ). Whereas sowing density had no effect on this frequency, the effect of moisture was significant at the 5 per cent level. Ninety-five per cent multiple confidence intervals showed a significant 
Table 1 B-chromosome constitution of survivors at four densities $(100,250,500$ and 1000 seeds per pot) and three watering regimes (normal, waterlogged and drought). A and B are replicates

\begin{tabular}{|c|c|c|c|c|c|c|c|c|c|c|c|c|c|c|c|c|}
\hline \multirow[b]{2}{*}{ Density } & \multirow{2}{*}{$\begin{array}{l}\text { Percentage } \\
\text { survival }\end{array}$} & \multicolumn{11}{|c|}{ B-chromosome number } & \multirow{2}{*}{$\begin{array}{l}\text { Total } \\
\text { plants }\end{array}$} & \multirow{2}{*}{$\begin{array}{l}\text { Percentage } \\
\text { of }+B \text { plants }\end{array}$} & \multirow{2}{*}{$\begin{array}{l}\text { Mean B } \\
\text { per plant }\end{array}$} & \multirow{2}{*}{$\begin{array}{l}\text { Mean B per } \\
\text { B-containing } \\
\text { plant }\end{array}$} \\
\hline & & 0 & 1 & 2 & 3 & 4 & 5 & 6 & 7 & 8 & 9 & $10+$ & & & & \\
\hline \multicolumn{17}{|l|}{ Normal } \\
\hline $100 \mathrm{~A}$ & 35.0 & 101 & 59 & 42 & 20 & 12 & 7 & 3 & 1 & 2 & 0 & 2 & 249 & 59.4 & 1.41 & 2.37 \\
\hline B & 34.8 & 112 & 50 & 45 & 16 & 12 & 5 & 4 & 3 & 0 & 3 & 0 & 250 & 55.2 & 1.33 & 2.41 \\
\hline $250 \mathrm{~A}$ & 33.3 & 117 & 52 & 38 & 17 & 17 & 3 & 4 & 0 & 1 & 0 & 0 & 249 & 53.0 & 1.18 & 2.23 \\
\hline B & 32.7 & 120 & 39 & 45 & 20 & 12 & 6 & 6 & 1 & 1 & 0 & 0 & 250 & 52.0 & 1.27 & 2.45 \\
\hline $500 \mathrm{~A}$ & 31.0 & 110 & 42 & 41 & 19 & 18 & 7 & 8 & 3 & 1 & 1 & 0 & 250 & 56.0 & 1.50 & 2.67 \\
\hline B & 22.6 & 112 & 52 & 27 & 26 & 16 & 6 & 3 & 2 & 4 & 1 & 1 & 250 & 55.2 & 1.44 & 2.62 \\
\hline $1000 \mathrm{~A}$ & 13.5 & 104 & 57 & 33 & 24 & 17 & 9 & 2 & 1 & 1 & 1 & 1 & 250 & 58.4 & 1.42 & 2.43 \\
\hline B & 18.9 & 106 & 55 & 38 & 23 & 12 & 11 & 3 & 2 & 0 & 0 & 0 & 250 & 57.6 & 1.34 & 2.33 \\
\hline Totals & & 882 & 406 & 309 & 165 & 116 & 54 & 33 & 13 & 10 & 6 & 4 & 1998 & 55.9 & 1.36 & 2.44 \\
\hline \multicolumn{17}{|c|}{ Waterlogged } \\
\hline $100 \mathrm{~A}$ & 37.0 & 99 & 54 & 38 & 27 & 13 & 9 & 5 & 1 & 2 & & 1 & 250 & 60.4 & 1.52 & 2.52 \\
\hline B & 30.8 & 105 & 44 & 26 & 21 & 13 & 4 & 5 & 1 & 3 & 1 & 0 & 223 & 52.9 & 1.35 & 2.55 \\
\hline $250 \mathrm{~A}$ & 27.6 & 100 & 58 & 36 & 18 & 17 & 9 & 3 & 3 & 3 & 3 & 0 & 250 & 60.0 & 1.55 & 2.58 \\
\hline B & 32.0 & 107 & 49 & 33 & 32 & 14 & 5 & 4 & 2 & 1 & 0 & 1 & 248 & 56.9 & 1.43 & 2.51 \\
\hline $500 \mathrm{~A}$ & 15.4 & 72 & 47 & 17 & 16 & 10 & 5 & 3 & 1 & 1 & 1 & 2 & 175 & 58.9 & 1.46 & 2.49 \\
\hline B & 18.8 & 94 & 56 & 42 & 25 & 14 & 8 & 4 & 5 & 0 & 1 & 1 & 250 & 62.0 & 1.55 & 2.49 \\
\hline $1000 \mathrm{~A}$ & 9.6 & 71 & 36 & 29 & 12 & 8 & 7 & 6 & 3 & 1 & 0 & 0 & 173 & 59.0 & 1.51 & 2.57 \\
\hline B & 5.5 & 83 & 22 & 17 & 16 & 5 & 5 & 4 & 1 & 0 & 0 & 1 & 154 & 46.1 & 1.23 & 2.68 \\
\hline Totals & & 731 & 366 & 238 & 167 & 94 & 52 & 34 & 17 & 11 & 7 & 6 & 1723 & 57.6 & 1.46 & 2.54 \\
\hline \multicolumn{17}{|l|}{ Drought } \\
\hline $100 \mathrm{~A}$ & 2.0 & 6 & 5 & 2 & 4 & 1 & 1 & 0 & 0 & 0 & 0 & $\begin{array}{l}1 \\
0\end{array}$ & $\begin{array}{l}20 \\
21\end{array}$ & $\begin{array}{l}70.0 \\
61.9\end{array}$ & $\begin{array}{l}2.00 \\
1.43\end{array}$ & $\begin{array}{l}2.86 \\
2.31\end{array}$ \\
\hline B & 2.1 & 8 & 5 & 3 & 2 & 2 & 1 & 0 & 0 & 0 & 0 & $\begin{array}{l}0 \\
0\end{array}$ & $\begin{array}{l}21 \\
54\end{array}$ & $\begin{array}{l}61.9 \\
55.6\end{array}$ & $\begin{array}{l}1.43 \\
1.44\end{array}$ & $\begin{array}{l}2.31 \\
2.60\end{array}$ \\
\hline $250 \mathrm{~A}$ & 2.2 & 24 & 10 & 8 & 2 & 5 & 4 & 1 & 0 & 0 & 0 & $\begin{array}{l}0 \\
0\end{array}$ & $\begin{array}{l}54 \\
37\end{array}$ & $\begin{array}{l}55.6 \\
73.0\end{array}$ & 1.41 & $\begin{array}{l}2.60 \\
1.93\end{array}$ \\
\hline B & 1.5 & 10 & 14 & 6 & 4 & 1 & 2 & 0 & 0 & 0 & 0 & 0 & 37 & $\begin{array}{l}73.0 \\
56.8\end{array}$ & 1.08 & $\begin{array}{l}1.93 \\
1.91\end{array}$ \\
\hline $500 \mathrm{~A}$ & 0.7 & 16 & 8 & 8 & 4 & 1 & 0 & 0 & 0 & 0 & 0 & 0 & 37 & $\begin{array}{l}56.8 \\
76.5\end{array}$ & 184 & \\
\hline B & 1.0 & 12 & 11 & 14 & 6 & 5 & 1 & 2 & 0 & 0 & 0 & 0 & 51 & 76.5 & 1.84 & 2.41 \\
\hline $1000 \mathrm{~A}$ & 0.6 & 27 & 11 & 5 & 9 & 4 & 2 & 3 & 1 & 1 & 0 & 0 & 63 & 57.1 & 1.70 & 2.97 \\
\hline B & 0.5 & 18 & 13 & 7 & 6 & 3 & 1 & 1 & 0 & 0 & 1 & 0 & 50 & 64.0 & 1.54 & 2.41 \\
\hline Totals & & 121 & 77 & 53 & 37 & 22 & 12 & 7 & 1 & 1 & 1 & 1 & 333 & 63.7 & 1.56 & 2.44 \\
\hline
\end{tabular}

difference between the normal and drought regimes (55.9 per cent cf. 63.7 per cent B-containing), but not between normal and waterlogged $(55.9$ per cent cf. 57.5 per cent B-containing); the difference between waterlogged and drought $(57.5$ per cent cf. 63.7 per cent B-containing) was nearly significant.

Analysis of variance, weighted for sample size, was carried out to examine the effect of sowing density and moisture treatment on the mean number of B-chromosomes per plant in the survivors. No significant effects were detectable (Table 4). Using log-linear analysis, the frequency distribution of the number of B-chromosomes per plant was also shown to be independent of sowing density and moisture treatment (Table 5).

Thirteen different types of B-chromosome were recorded amongst the survivors (Table 2). None of these have been described previously (Bougourd \& Parker, 1975; Bougourd \& Parker, 1979a; Holmes \& Bougourd, 1989). The four novel B-types included two metacentric Bs of approximately 1.6 and $5.8 \mu \mathrm{m}$ in length, designated $\mathrm{B}^{\mathrm{m}-4}$ and $\mathrm{B}^{\mathrm{m}-5}$, and two submetacentric Bs of approximately 2.0 and $6.1 \mu \mathrm{m}$ designated $\mathrm{B}^{\mathrm{SM}-2}$ and $\mathrm{B}^{\mathrm{SM}-5}$. By far the most frequent $\mathrm{B}$ type, accounting for 89 per cent of the B chromosomes, was the standard $\mathrm{B}^{\mathrm{t}-1}$ of the non-standard $\mathrm{Bs}, \mathrm{B}^{\mathrm{m}-1}(4.6$ per cent $), B^{t-2}(3.1$ per cent $), B^{t-3}(2.2$ per cent $)$ and $\mathrm{B}^{\mathrm{t}-4}(0.6$ per cent $)$ occurred most commonly; the other non-standard B-types were represented only occasionally.

The frequency of non-standard B-chromosomes 


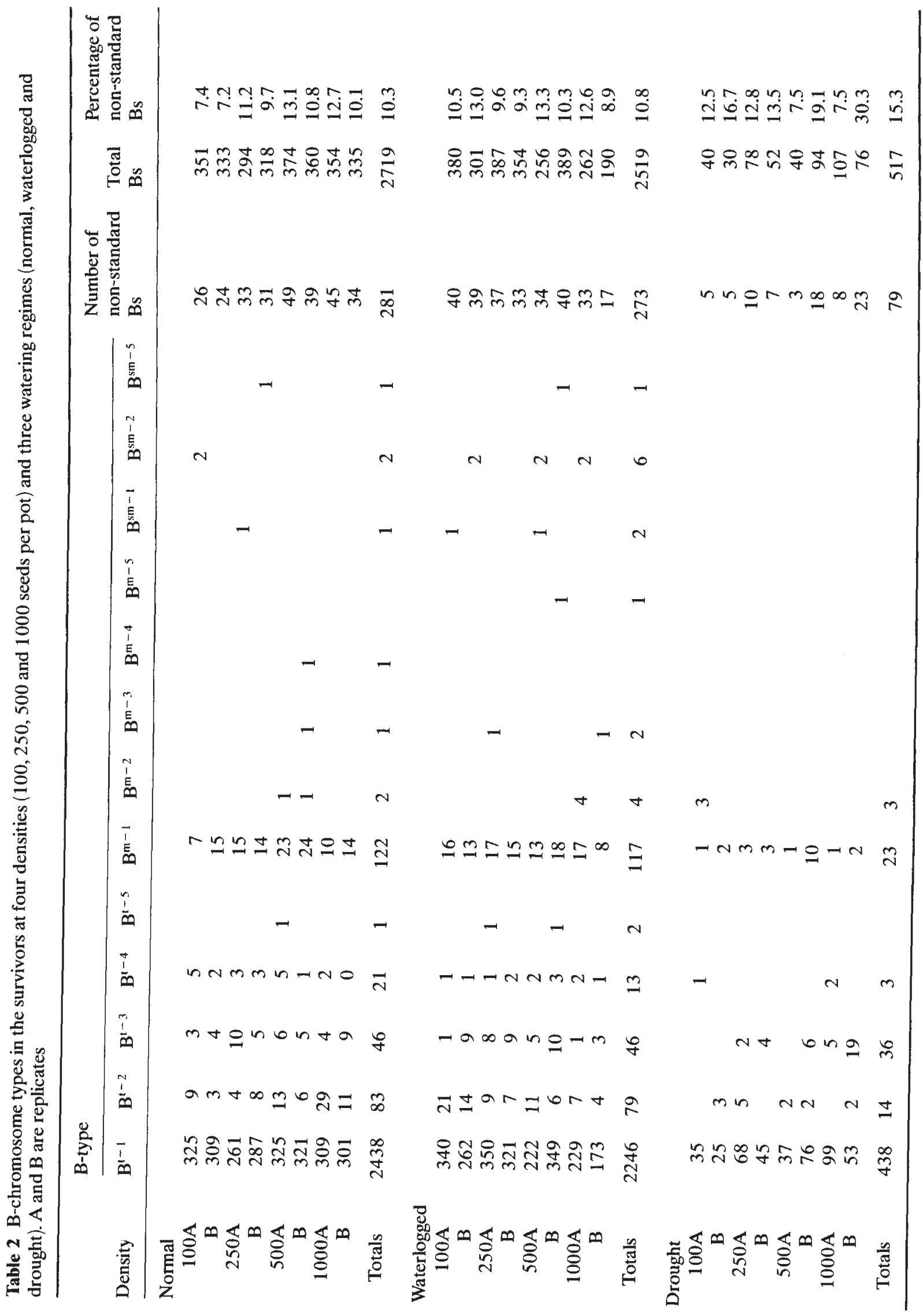


Table 3 Logit analysis of the occurrence of B-containing plants in the survivors of four sowing densities $(100,250$, 500 and 1000 seeds per pot) and three watering regimes (normal, waterlogged and drought)

\begin{tabular}{llll}
\hline Source* & d.f. & $\begin{array}{l}\text { Log-likelihood } \\
\text { ratio statistic }\end{array}$ & Significance \\
\hline Density & 3 & 1.90 & ns \\
Moisture & 2 & 7.54 & $P<0.05$ \\
Density $\times$ moisture & 6 & 7.88 & ns \\
\hline
\end{tabular}

*Since the design is non-orthogonal, the order of inclusion of terms is important. Only one order is shown here. All permutations gave similar results.

Table 4 Analysis of variance, weighted for sample size, to compare mean B-number in survivors of four sowing densities (100, 250, 500 and 1000 seeds per pot) and three watering regimes (normal, waterlogged and drought)

\begin{tabular}{lrrrlll}
\hline Source* & d.f. & \multicolumn{1}{l}{$S S$} & $M S$ & $F$ & Significance \\
\cline { 1 - 4 } All survivors & & & & & \\
$\quad$ Density & 3 & 8.92 & 2.97 & 1.17 & $\mathrm{~ns}$ \\
$\quad$ Moisture & 2 & 16.20 & 8.10 & 3.05 & $\mathrm{~ns}$ \\
Density $\times$ moisture & 6 & 13.27 & 2.21 & 0.83 & $\mathrm{~ns}$ \\
Error & 12 & 31.92 & 2.66 & & \\
$\quad$ Total & 23 & 70.31 & & & \\
& & & & & \\
B-containing & & & & & \\
$\quad$ survivors only & & & & & \\
$\quad$ Density & 3 & 6.95 & 2.32 & 0.76 & $\mathrm{~ns}$ \\
$\quad$ Moisture & 2 & 11.27 & 5.64 & 1.85 & $\mathrm{~ns}$ \\
$\quad$ Density $\times$ moisture & 6 & 40.26 & 6.71 & 2.20 & $\mathrm{~ns}$ \\
Error & 12 & 36.56 & 3.05 & & \\
$\quad$ Total & 23 & 95.04 & & & \\
\hline
\end{tabular}

*Since the design is non-orthogonal, the order of inclusion of terms is important. Only one order is shown here. All permutations gave similar results.

between regimes was compared by logit analysis (Table 6 ). The effect of moisture was significant at the 5 per cent level. Ninety-five per cent multiple confidence intervals showed a significant difference between the drought (15.3 per cent non-standard) and both the normal (10.3 per cent) and waterloggged (10.8 per cent) regimes, which were themselves not significantly different.

\section{Discussion}

These experiments have shown that moisture conditions, especially drought, can affect the proportion of plants amongst the survivors which contain B-chromosomes, and they provide clear evidence for the differential fitness of B-containing and non-B-containing
Table 5 Log-linear analysis to compare the frequency distributions of B-number amongst the survivors of four sowing densities $(100,250,500$ and 1000 seeds per pot) and three watering regimes (normal, waterlogged and drought)

\begin{tabular}{lrll}
\hline Source* & d.f. & $\begin{array}{l}\text { Log-linear } \\
\text { ratio statistic }\end{array}$ & Significance \\
\hline All survivors & & & \\
$\quad$ Density & 30 & 16.5 & ns \\
$\quad$ Moisture & 20 & 18.4 & ns \\
$\quad \begin{array}{l}\text { Density } \times \text { moisture } \\
\text { B-containing }\end{array}$ & 192 & 198.8 & ns \\
$\quad$ survivors only & & & \\
$\quad$ Density & 27 & 14.6 & ns \\
$\quad$ Moisture & 18 & 11.2 & ns \\
$\quad$ Density $\times$ moisture & 174 & 176.8 & ns \\
\hline
\end{tabular}

*Since the design is non-orthogonal, the order of inclusion of terms is important. Only one order is shown here. All permutations gave similar results.

Table 6 Logit analysis of the occurrence of non-standard B-chromosomes in the survivors of four sowing densities $(100,250,500$ and 1000 seeds per pot $)$ and three watering regimes (normal, waterlogged and drought)

\begin{tabular}{llll}
\hline Source* & d.f. & $\begin{array}{l}\text { Log-likelihood } \\
\text { ratio statistic }\end{array}$ & Significance \\
\hline Density & 3 & 7.01 & ns \\
Moisture & 2 & 9.08 & $P<0.05$ \\
Density $\times$ moisture & 6 & 7.62 & ns \\
\hline
\end{tabular}

*Since the design is non-orthogonal, the order of inclusion of terms is important. Only one order is shown here. All permutations gave similar results.

plants under drought conditions. Differential survival of B-containing individuals, under extreme stress, has previously been demonstrated in Secale cereale and Lolium perenne (Rees \& Hutchinson, 1973; Hutchinson, 1975; Teoh et al., 1976; Teoh \& Jones, 1978). In Secale cereale, the frequency of $\mathrm{Bs}$ was found to decrease under conditions of increasing stress, whereas in Lolium perenne, as in Allium schoenoprasum under drought conditions, B-chromosomes were shown to confer a selective advantage to survival.

In $A$. schoenoprasum, less than 3 per cent of the seeds germinated and survived the experimental period of 38 weeks under drought conditions. The stress arising from drought was considerably more intense than that imposed by the maximum sowing density of 1000 seeds per pot, where germination and survival of seedlings under normal watering conditions was greater than 16 per cent. Under the drought conditions, relatively few seeds germinated sporadically over a prolonged period but, once germinated, seedlings 
tended to survive to the end of the 38-week period. This suggests that the higher proportion of B-containing individuals amongst the survivors is due to the superior ability of B-containing seeds to germinate under these stringent conditions. One explanation of this might be that seeds with B-chromosomes require smaller quantities of water for imbibition prior to successful germination. Seed weight has previously been shown in $A$. schoenoprasum to be significantly reduced with increasing numbers of Bs (Bougourd \& Parker, 1979b). If, as is likely, seed size depends similarly on the number of Bs, the amount of moisture necessary to break the dormancy of B-containing seeds could be less, and the probability of B-containing seeds germinating would be increased. There is evidence that the germination of seeds from the River Wye is extremely rapid compared with other British, nonriverside populations, presumably as a consequence of intense selection for early germination in this riverside habitat (Bougourd, 1977). A small difference in the speed of germination of seeds due to B-chromosomes could, therefore, also have a significant effect on the survival of B-containing individuals. No effect of B-chromosomes on the rate of germination has been detected in A. schoenoprasum in previous experiments (Bougourd \& Parker, 1979b), but these were carried out under favourable growth-room conditions and were not designed to pick up very small differences in the germination rate. Further experiments on the relative ability and rate of germination of B-containing seeds in limited amounts of moisture are clearly necessary in order to establish more precisely the nature of the advantage due to B-chromosomes for the survival of individuals under drought conditions.

In our studies of the survival of individuals containing B-chromosomes at the River Wye, we found that non-standard B-types were significantly less frequent amongst the seedlings relative to the seeds (Holmes \& Bougourd, 1989). This did not seem surprising because it is likely that the non-standard derivatives of the standard type of B-chromosome may fare less well than the standard Bs which have presumably evolved over successive generations in response to the conditions at the River Wye. In the present experiments, we have again shown that drought conditions have a significant effect on the frequency of non-standard B-types but we were interested to note that the effect was to increase these types at the expense of standard B-chromosomes. The increase was almost entirely due, however, to the greater occurrence of $\mathrm{B}^{\mathrm{t}-3}$ in the survivors of the drought conditions; 7 per cent of the B-chromosomes in the drought survivors were of this type compared with less than 2 per cent in the normal and waterlogged conditions. A small increase in the frequency of $B^{t-3}$ was also found in the seedlings in the previous study (Holmes \& Bougourd, 1989), but this was more than offset by the marked increase in the standard B-type. $\mathrm{B}^{\mathrm{t}-3}$ is approximately 33 per cent longer than the standard $\mathrm{B}^{\mathrm{t}-1}$ and relatively unstable at mitosis (Bougourd \& Parker, 1979a). It will be interesting to monitor the frequency of this particular B-type in future generations in the natural populations at the River Wye.

\section{Acknowledgements}

We are very grateful to $\mathrm{Mr} \mathbf{J}$. H. Wilson for allowing us access to the study area at the River Wye and for the interest he has shown in our work. We would also like to thank Mr J. Byrne and Dr T. J. Crawford for their invaluable statistical advice. We gratefully acknowledge the award of a studentship from NERC to DSH.

\section{References}

BOUGOURD, S. M. 1977. The genetics and cytology of natural populations of Allium schoenoprasum. PhD Thesis, University of London.

BOUGOURD, S. M. \& PARKER, J. S. 1975. The B-chromosome system of Allium schoenoprasum. I. B-distribution. Chromosoma (Berlin), 53, 273-282.

BOUGOURD, S. M. \& PARKER, J. s. 1979a. The B-chromosome system of Allium schoenoprasum II. Stability, inheritance and phenotypic effects. Chromosoma (Berlin), 75, 369-383.

BoUgourd, S. M. \& PARKER, J. S. 1979b. The B-chromosome system of Allium schoenoprasum III. An abrupt change in B-frequency. Chromosoma (Berlin), 75, 385-392.

DARlington, C. D. 1956. Chromosome Botany, George, Allen \& Unwin Ltd, London.

HOLMES, D. S. \& BOUGOURD, S. M. 1989. B-chromosome selection in Allium schoenoprasum I. Natural populations. Heredity, 63, 83-87.

HUTCHINSON, J. 1975. Selection of B chromosomes in Secale cereale and Lolium perenne. Heredity, 34, 39-52.

JONES, R. N. 1975. B-chromosome systems in flowering plants and animal species. Int. Rev. Cytol., 40, 1-100.

JONES, R. N. \& REES, H. 1982. B. chromosomes. Academic Press, London.

MATTHEWS, R. B. \& JONES, R. N. 1983. Dynamics of the B chromosome polymorphism in rye. II. Estimates of parameters. Heredity, 50, 119-138.

NUR, U. 1977. Maintenance of a 'parasite' B-chromosome in the grasshopper Melanopus femur-rubrum. Genetics, 87, 499-512.

OSTERgren, G. 1945. Parasitic nature of extra fragment chromosomes. Botan. Notis., 2, 158-163.

REES, H. \& HUTCHINSON, J. 1973. Nuclear DNA variation due to B chromosomes. Cold Spring Harbor Symp. Quant. Biol., 38, 175-182.

TEOH, S. B. \& JONES, R. N. 1978. B chromosome selection and fitness in rye. Heredity, 41, 35-48.

TEOH, S. B., REES, H. \& HUTCHINSON, J. 1976. B chromosome selection in Lolium. Heredity, 37, 207-213. 